\title{
PERAN MIKROBA ENDOFITIK PADA BIJI KARET (Hevea Brasiliensis) TERHADAP PERKECAMBAHAN DAN PERTUMBUHAN AWAL TANAMAN
}

\author{
Role of Endophytic Microbes on Rubber Seed (Hevea brasiliensis) to \\ Germination and Early Plant Growth \\ Radite Tistama dan Cici Indriani Dalimunthe \\ Balai Penelitian Sungei Putih, PO. BOX. 1415 Medan 20001 \\ Email: raditetistama@gmail.com
}

Diterima 4 Agustus 2017 / Direvisi 29 Oktober 2017 / Disetujui 30 Oktober 2017

\begin{abstract}
Abstrak
Perkecambahan dan pertumbuhan awal biji karet bervariasi dipengaruhi oleh tingkat kesegaran biji. Mikroba endofitik dalam biji berperan penting dalam menjaga viabilitas biji karet. Penelitian ini bertujuan untuk menguji peran beberapa mikroba endofitik di dalam biji karet segar maupun biji kurang segar terhadap pertumbuhan biji karet. Rancangan penelitian yang digunakan adalah Rancangan Acak Lengkap (RAL) non faktorial dengan tujuh perlakuan dan lima ulangan. Hasil penelitian menunjukkan bahwa Trichoderma viridae, T.koningii dan Aspergillus flavus yang merupakan mikroba endofitik di dalam biji karet segar mampu menekan pertumbuhan Penicillium sp. secara in vitro. Mikroba endofitik tersebut berpengaruh nyata dalam mempercepat masa perkecambahan biji karet, pertumbuhan awal tanaman dan mempengaruhi arsitektur akar tanaman karet.
\end{abstract}

Kata kunci: Hevea brasiliensis, mikroba endofitik, perkecambahan biji

\section{Abstract}

Germination and early growth of rubber tree seed were affected by freshness level of the seed. Endophytic microbes were predicted have an important role in the keeping of seed viability. The research objective was to test the role of the endophytic microbe in fresh and less fresh of the rubber seeds in germination and early growth of rubber seedling. The research was used a Completely Randomized Design non-factorial with seven treatments and five replications. The results showed that Trichoderma viridae, T. koningii and Aspergillus flavus that isolated from high vigorous rubber seed were able to inhibit seed Penicillium $s p$ in vitro. Theendophytic microbes have a significant effect in Hevea seeds accelerates seed germination, plant growth and affected to the root architecture of seedling.

Keywords: Hevea brasiliensis, endophytic microbe, seed germination

\section{Pendahuluan}

Biji karet masih mempunyai peranan strategis sebagai sumber batang bawah (rootstock) dalam perbanyakan tanaman karet. Kualitas batang bawah berperan dalam mendukung pertumbuhan klon (scion). Viabilitas biji menentukan kualitas batang bawah. Beberapa faktor seperti kelembaban, suhu dan lama penyimpanan menentukan penurunan viabilitas biji (Welty et al., 1987). Djaafar et al. (2001) menyebutkan bahwa kemunduruan viabilitas juga dapat disebabkan oleh aktivitas mikrobia selama penyimpanan. Keberadaan patogen pada benih akan memberikan epidemi penyakit dan menjadi sumber penyebaran patogen (Ilyas, 2001). 
Usaha penyediaan benih yang bebas patogen dan berdaya tumbuh baik sangat penting dilakukan untuk mendapatkan pertumbuhan yang optimal di lapangan. Biji bebas penyakit diperoleh secara konvensional dengan menyelubungi biji dengan pestisida untuk mencegah serangan penyakit selama penyimpan atau pengiriman (Mari \& Guizzardi, 1998). Pendekatan terbaru untuk menghambat infeksi patogen pada benih dicegah dengan pelapisan benih (coating) menggunakan mikroba antagonis (Sukarman \& Seswita, 2012). Mikroba antagonis adalah mikroorganisme yang dapat menghambat atau menyerang mikroba lain yang tidak dikehendaki dan dikenal sebagai agen hayati pengendalian patogen tanaman (Hanudin et al., 2002).

Agen hayati dapat berasal dari mikroba endofitik. Mikroba endofitik umumnya sebagai simbion dan dapat berada di seluruh bagian jaringan tumbuhan, baik di jaringan akar, batang maupun daun. Setiap spesies tanaman mempunyai mikroba endofitik yang dengan karakter yang khas. Mikroba endofitik yang paling umum ditemukan pada tanaman kehutanan adalah dari jenis fungi (Unterseher, 2011; Osono, 2014). Mikroba endofitik dapat melindungi tumbuhan inang dari serangan patogen dengan berbagai mekanisme (Ting, 2014). Salah satunya, mikroba endofitik mengeluarkan senyawa metabolit sekunder berupa senyawa bioaktif yang dapat berfungsi menghambat perkembangan mikroba patogen (Ge et al., 2008).

Selain senyawa antimikroba patogen, sebagian mikroba endofitik memproduksi Plant Growth Promotion (PGP) (Malfanova, 2013). PGP yang dihasilkan oleh endofitik sebagian besar dapat berupa nutrisi penting bagi tanaman atau fitohormon. Nassar et al. (2005) melaporkan sejenis PGP ditemukan pada isolat jamur Williopsis saturnus, jamur endofitik di dalam akar jagung. Jamur endofitik ini menghasilkan indole-3-acetic acid (IAA) dan indole-3-piruvat acid (IPYA) secara in vitro di dalam media kultur jamur. Aplikasi jamur endofitik tersebut menghasilkan peningkatan bobot kering akar, panjang akar, dan panjang tunas bibit tanaman jagung dibandingkan dengan tanaman kontrol. Bakteri endofitik juga dilaporkan dapat meningkatkan toleransi cekaman abiotik seperti kekeringan melalui mekanisme sintesis asam salisalat dan asam jasmonat untuk menghambat asam absisat (Waqas et al., 2012).

Kemampuan biokontrol bakteri terhadap patogen dapat didasarkan pada beberapa mekanisme seperti antibiosis, kompetisi nutrisi dan tempat serta menginduksi resistensi sistemik tanaman. Sejauh ini, peran mikroba endofitik sebagai penginduksi resistensi sistemik telah dikonfirmasi pada tanaman terinfeksi penyakit. Hal ini diketahui dari pengamatan mikroskopik bakteri endofitik di dalam tanaman yang menyebabkan perubahan morfologi pada jaringan yang terinfeksi dan mengurangi gejala penyakit di lokasi yang bakteri endofitik itu sendiri tidak ada (Griffin, 2014).

Variasi viabilitas biji karet cukup tinggi, berkisar 40-95\% dari biji yang dihasilkan dalam setiap musim biji. Hingga saat ini belum ada informasi peran mikroba endofitik mempengaruhi viabilitas biji karet terhadap pertumbuhan awal tanaman. Eksplorasi mikroba endofitik di dalam biji karet belum pernah dilaporkan sebelumnya. Penelitian ini bertujuan untuk menguji peran mikroorganisme endofitik di dalam biji karet segar terhadap perkembangan biji menjadi tanaman karet.

\section{Bahan dan Metode}

Penelitian ini dilaksanakan di Laboratorium Proteksi dan Rumah Kaca Balai Penelitian Sungei Putih. Rancangan yang digunakan pada penelitian ini adalah Rancangan Acak Lengkap (RAL) non faktorial dengan tujuh perlakuan dan lima ulangan, setiap ulangan terdiri dari 10 biji. Bahan yang digunakan adalah biji karet klon PB260 yang segar dan kurang segar. Kesegaran biji ditentukan dengan memecahkan kulit biji. Biji karet segar ditandai dari tekstur biji yang 
lebih kenyal, sementara tekstur biji karet tidak segar lebih lembek (Gambar 1). Biji-biji dari kedua tipe tekstur tersebut diambil sampel dan dibelah membujur untuk memastikan kualitas bijinya. Biji dikoleksi dari kebun percobaan Balai Penelitian Sungei Putih. Media tumbuh jamur yang digunakan adalah Potato Dextrose Agar (PDA) dan Nutrient Agar (NA) untuk bakteri.

\section{Karakterisasi Mikroba Endofitik}

Jamur dan bakteri endofitik yang dikarakterisasi adalah hasil isolasi menggunakan metode sporulasi (Novariza et al., 2015). Mikroba dikarakterisasi berdasarkan ciri-ciri koloni secara makro skopis dengan mengamati warna, bentuk, perkembangan dan luas pertumbuhan mikroorganisme dan pengamatan morfologi dengan mikroskop.

\section{Uji Penghambatan Mikroba Endofitik Biji Karet Segar}

Pengujian daya antagonis jamur dilakukan dengan metode biakan ganda (dual culture) yaitu dengan cara mengambil koloni masingmasing biakan murni jamur hasil eksplorasi menggunakan cock borer diameter $4 \mathrm{~mm}$. Jamur terbawa benih dari biji segar dan tidak segar diinokulasikan pada cawan petri yang berisi media potato dextrose agar (PDA) untuk kemudian diuji dengan cara dual culture. Satu koloni Penicillium sp. dari biji karet kurang segar diinokulasikan pada medium PDA dengan jarak $30 \mathrm{~mm}$ terhadap mikroba endofitik dari biji karet segar. Pengujian daya hambat bakteri hasil eksplorasi dari biji segar dilakukan cara mencampurkan bakteri pada media PDA, kemudian koloni jamur Penicillium sp. diinokulasikan di bagian tengah media. Sebagai kontrol jamur Penicillium sp. ditumbuhkan secara tunggal pada medium PDA. Pengamatan pertumbuhan jamur dilakukan dengan pengukuran jari-jari koloni jamur pada 4 hari setelah inokulasi (HSI). Persentase penghambatan dilakukan dengan membagi luas jamur patogen pada media dual culture dibagi luas pertumbuhan di media kontrol(Suryanto \& Munir, 2006).

\section{Uji perkecambahan}

Biakan murni masing-masing mikroba endofitik hasil eksplorasi diencerkan dengan kerapatan $10^{9} \mathrm{CFU}$ untuk bakteri dan $10^{6}$ spora untuk jamur menggunakan akuades. Biji karet yang sehat disterilisasi permukaan menggunakan $5 \%$ natrium hipoklorit kemudian dicelupkan ke masing-masing jenis mikroba endofitik sebagai seed coating (pelapis biji). Selanjutnya biji dikecambahkan pada bak perkecambahan yang berisi pasir steril selama 21 hari untuk melihat stadia perkecambahan biji karet. Setelah 21 hari, kecambah

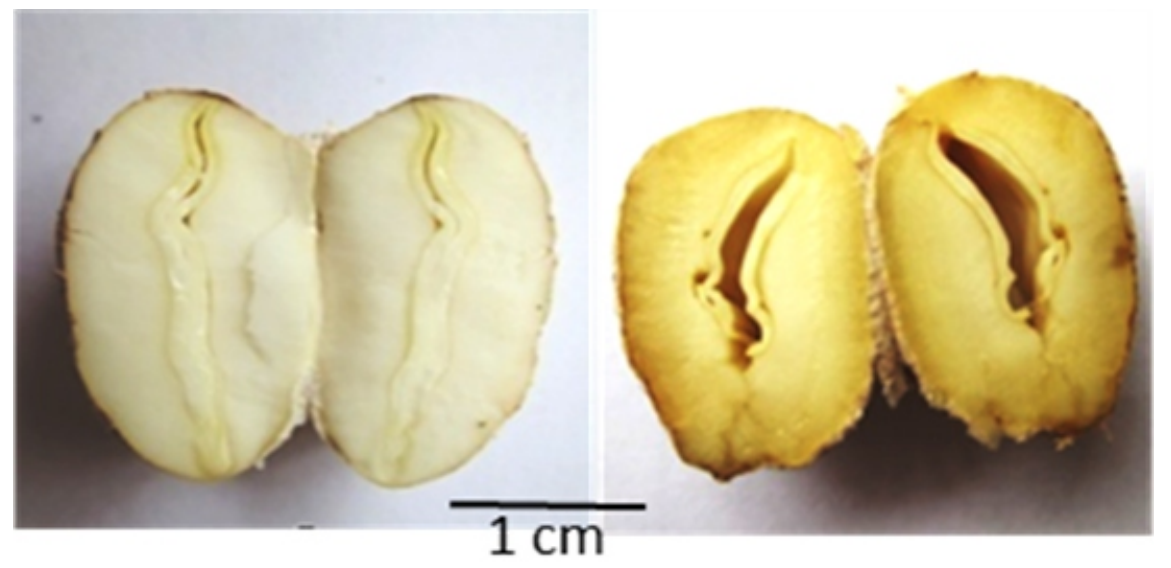

Gambar 1. Penampang membujur biji karet segar (kiri) dan biji karet kurang segar (kanan). 
dipindahkan ke polibag yang berisi media tanam tanah, pasir, dan kompos dengan perbandingan $1: 1: 1$. Tanaman kemudian diamati pertumbuhannya selama 1 bulan. Pemeliharaan tanaman dilakukan dengan melakukan penyiraman setiap pagi dan sore hari atau disesuaikan dengan kondisi rumah kaca dan juga dilakukan pada saat penyiangan.

\section{Kecepatan berkecambah (hari)}

Biji yang telah berkecambah diamati waktu yang dibutuhkan untuk mencapai setiap tahapan stadia perkecambahannya. Stadia perkecambahan biji karet terdiri dari stadia bintang ( \pm 0 - 5 hari), pancing ( \pm 6 - 10 hari), dan jarum ( \pm 11 - 15 hari). Pengamatan pada stadia perkecambahan dilakukan maksimal selama 21 hari.

\section{Pengukuran tinggi tanaman dan panjang akar}

Setelah biji dikecambahkan selama \pm 21 hari, semua biji yang berecambah pada setiap perlakuan ditanam di polibag. Pengukuran tinggi tanaman dilakukan setiap 2 minggu sekali selama 1 bulan setelah tanam. Tinggi tanaman diukur menggunakan meteran mulai dari batang di atas permukaan tanah hingga ujung tanaman. Panjang akar diukur dari leher akar sampai ujung akar lateral yang paling panjang. Panjang akar diukur pada tanaman yang telah berumur 4 minggu setelah tanam (MST).

\section{Hasil dan Pembahasan}

\section{Karakterisasi dan identifikasi mikro- organisme}

Hasil eksplorasi mikroba dari biji karet segar diperoleh empat isolat jamur dan dua isolat bakteri. Berdasarkan karakter morfologi koloni, warna koloni dan mikroskopik telah diketahui bahwa empat jamur tersebut adalah Trichoderma viridae, Trichoderma koningii, Aspergillus flavus dan Rhizopus sp. Ciri dua bakteri adalah warna krem dan coklat, permukaan koloni cekung, dan analisis dengan menggunakan pewarnaan gram keduanya termasuk ke dalam bakteri gram positif. Karakterisasi lebih spesifik mengenai kedua bakteri tersebut masih diperlukan untuk mengetahui spesies bakteri. Karakterisasi secara molekuler biasanya dilakukan dengan menggunakan 16S rRNA (Pohjanen et al., 2014) atau gen sitrat sintase (Tistama et al., 2013).

Aktivitas isolat A.flavus dan $T$. viridae, dan $T$. koningii diduga menjadi salah satu faktor yang dapat menjaga agar biji tidak mudah rusak oleh infeksi patogen karena metabolit yang dihasilkan jamur patogen. A. flavus diketahui mensekresikan asam salisilat dan asam jasmonat yang dapat menginduksi resistensi tanaman terhadap infeksi penyakit (Angel et al., 2011). Asam salisilat di dalam jaringan tanaman berperan dalam mekanisme resistensi lokal seperti kematian sel inang atau menginduksi ekspresi gen resistensi. Sistem resistensi sistemik kemudian disebarkan keseluruh jaringan tanaman (Vlot et al., 2009). Selain mensintesis asam salisilat, satu spesies mikrobia dapat menghasilkan beberapa zat yang memiliki fungsi spesifik yaitu IAA, $\mathrm{HCN}$ dan sidefore (Nandhini et al., 2012).

Isolasi mikroba endofitik dari biji karet yang kurang segar hanya diperoleh satu isolat jamur yang termasuk dalam kelompok Penicilium sp. dan tidak diketemukan isolat dari kelompok bakteri. Peranan Penicillium sp di dalam biji karet yang mempunyai viabilitas rendah belum diketahui, sebagai penyebab primer atau sekunder terhadap kerusakan jaringan. Kemungkinan lain adalah hanya Penicillium sp. yang mampu bertahan hidup pada kondisi biji tersebut. Metabolisme di dalam jaringan tanaman diketahui mempengaruhi terhadap metabolisme mikroba endofitik (Tenguria et al., 2011). Biji karet diketahui menghasilkan hidrogen sianida $(\mathrm{HCN})$ yang mengakibatkan viabilitas biji menurun. HCN ini sebagian digunakan 
sebagai prekusor produk-produk turunan HCN seperti sianogenik glikosida. Pada kondisi HCN tinggi, hanya Penicillium sp. masih dapat bertahan hidup di dalam biji karet.

Peran masing-masing jamur dan bakteri di dalam biji yang segar belum diketahui secara pasti. Menurut Resende et al. (2014), Trichoderma endofitik tidak menghasilkan giberelin, sitokinin maupun auksin seperti halnya isolat-isolat dari rhizosfere. Selama perkembangan biji sejak antesis telah diketahui bahwa, peran kandungan IAA sangat menentukan keberhasilan calon biji menjadi biji yang sempurna (Sulistiono et al., 2004). Trichoderma sp. dan Aspergillus flavus pada biji karet juga menghasilkan PGP yang berperan pada perkembangan biji. Di samping juga menghasilkan metabolit tertentu yang dapat melindungi biji, hal tersebut masih perlu diteliti lebih lanjut.

\section{Penghambatan Mikroba Endofitik}

Uji antagonis mikroba endofitik dari biji karet segar terhadap jamur Penicillium sp. dari biji kurang segar secara in vitro menunjukkan bahwa beberapa jamur endofitik mampu menghambat pertumbuhan Penicillium sp. Penelitian (Novariza et al., 2015) menyebutkan Penicillium sp. merupakan jamur yang banyak tumbuh pada biji karet kurang segar sehingga diduga mempengaruhi kesegaran biji karet.

Kriteria keefektifan antagonisme jamurjamur tersebut secara in vitro dilihat dari terbentuk atau tidaknya zona hambatan, yaitu zona bening diantara patogen dan agens antagonis (Maria, 2002). Jamur endofitik dari biji segar memiliki daya hambat terhadap Penicillium sp. lebih tinggi dibandingkan dengan bakteri. Aspergillus sp. mampu menekan perkembangan miselium Penicillium sp. paling tinggi diikuti oleh Trichoderma koningii dan Trichoderma viridae. Sementara daya hambat Rhizopus sp. dan dua bakteri yang diuji dinilai rendah karena daya hambatnya kurang dari 50\%. Hasil penelitian Ratnasari et al. (2014) menunjukkan bahwa Aspergillus sp. memiliki kemampuan dalam menghambat pertumbuhan jamur karena memproduksi enzim hidrolitik seperti lipase, protease, selulase, pektinase.

Penicillium sp. sebenarnya juga menghasilkan metabolit antimikroba yang disebut penicidones ( $\mathrm{Ge}$ et al., 2008). Penicillium sp. pada penelitian ini tidak menghasilkan penicidones sehingga tidak menghambat mikroba endofitik lainnya. Sinergi diantara keenam mikroba tersebut diduga akan dapat meningkatkan perannya terhadap penghambatan mikroba patogen yang dapat merusak biji dan mempertahankan kesegaran biji.

Biji karet segar didominasi oleh Trichoderma viridae, Aspergillus sp. dan Trichoderma koningii (Gambar 2). Kemungkinan dominasi beberapa mikroba tersebut di dalam biji karet dapat meningkatkan kualitas biji berkaitan dengan kompetisi penyerapan nutrisi yang dibutuhkan mikroba perusak. Selain itu, ketiga jamur tersebut diduga menghasilkan antimikroba tertentu yang secara spesifik menghambat mikroba patogen yang terbawa biji kurang segar. Menurut Malfanova (2013) mikroba endofitik dapat menekan mikroba lain dengan mekanisme kompetisi nutrisi dan dominasi tempat (niche). Sebagian besar mikroba endofitik yang diisolasi dari tanaman kehutanan menghasilkan zat-zat yang menghambat perkembangan bakteri (Schueffler \& Anke, 2011).

\section{Pengaruh Mikroba Endofitik Pada Perkecambahan Biji Karet}

Tahapan perkecambahan biji karet dibagi menjadi tiga stadia berdasarkan bentuk dari kecambah yaitu stadia bintang, pancing dan jarum (Siagian, 2008). Peran fisiologis keenam mikroba diuji berkaitan dengan perannya dalam proses perkecambahan biji karet. Biji karet dibalut dengan mikroba endofitik dari biji karet segar yang dikenal dengan seed coating (Sukarman \& Seswita, 2015). Perlakuan seed 




Gambar 2. Daya hambatan mikroba dari biji karet sehat terhadap mikroba Penicilium sp. dari biji karet kurang segar pada 4 hari setelah inokulasi (HSI). Dominasi jamur endofitik terhadap Penicillium sp diduga mempengaruhi kesegaran biji karet.

coating dengan jamur dan bakteri endofitik ini terbukti mempercepat perkecambahan biji karet. Stadia bintang dapat dicapai dalam waktu dua kali lebih cepat dibandingkan tanpa coating kecuali coating dengan Rhizopus sp. Biji karet yang tidak dibalut dengan mikroba endofitik rata-rata mencapai stadia bintang pada 7 hari, sementara biji yang dibalut stadia bintang dicapai dalam 2,33 3,00 hari (Tabel 1). Biji karet yang diperlakukan dengan Rhizopus sp. berkecambah pada 6 hari atau lebih cepat 1,75 hari dibandingkan kontrol. Meskipun demikian jamur ini memberikan pengaruh nyata terhadap percepatan perkecambahan biji karet.

Secara konsisten jamur Trichoderma sp., Rhizophus sp. dan Aspergillus sp. mempercepat pertumbuhan awal biji karet dari mulai stadia bintang hingga stadium jarum. Kemampuan Trichoderma sp. dalam menginduksi pertumbuhan kecambah biji kakao telah dilaporkan oleh Bailey et al. (2011). Hasan (2002) melaporkan bahwa bagaimana Aspergillus sp. dapat berperan pada pertumbuhan tanaman yaitu dengan menghasilkan zat pengatur tumbuh (ZPT) giberelin dan auksin. Secara umum giberelin dibutuhkan dalam mengaktifkan proses perkecambahan biji (Waqas et al., 2012; Taiz \& Zeiger, 2002) menyebutkan beberapa jamur endofitik mampu menghasilkan Ga1, Ga3, $\mathrm{Ga} 4$ dan $\mathrm{Ga} 7$ yang dapat meningkat biomassa tanaman inangnya. Pemberian giberelin eksogenous bahkan meningkatkan perkecambahan biji pada kondisi cekaman Natrium (Hasan, 2002). Auksin berperan dalam aktivitas meristem pucuk dan memicu perkembangan tunas-tunas apikal ataupun tunas lateral (Taiz \& Zeiger, 2002). Trichoderma dapat menghasilkan beberapa zat pengatur tumbuh (ZPT) seperti indole-3-acetic acid, indole3-acetaldehyde, dan indole-3-ethanol. ZPT tersebut mengatur arsitektur akar dan dibutuhkan dalam perkecambahan biji. Hasil penelitian Akbari et al. (2007) membuktikan bahwa pemberian IAA pada kecambah tanaman gandum yang dicekam $\mathrm{Na}$ dapat meningkatkan pertambahan berat kering dan panjang hipokotil, tetapi tidak meningkatkan persentase perkecambahan.

Pelapisan biji dengan mikroba dapat mempersingkat perkecambahan. Biji karet secara konvensional memerlukan 7 hari untuk proses perkecambahan (Siagian, 2008) dan mencapai stadia pancing pada 10-12 hari. Dari hasil penelitian ini waktu perkecambahan tersebut dapat dipersingkat 2 - 4 hari, sehingga 
Tabel 1. Kecepatan berkecambah \& biji karet segar yang dilapisi dengan mikroba pada beberapa stadia perkecambahan biji.

\begin{tabular}{lccc}
\hline \multirow{2}{*}{ Perlakuan } & \multicolumn{3}{c}{ Kecepatan berkecambah (hari) } \\
\cline { 2 - 4 } & Bintang & Pancing & Jarum \\
\hline Kontrol & $7,00 \mathrm{a}$ & $10,07 \mathrm{a}$ & $11,12 \mathrm{a}$ \\
T. viridae & $2,67 \mathrm{c}$ & $4,33 \mathrm{~d}$ & $5,33 \mathrm{c}$ \\
T. koningii & $2,33 \mathrm{c}$ & $4,67 \mathrm{~d}$ & $6,00 \mathrm{c}$ \\
Aspergillus sp. & $3,00 \mathrm{c}$ & $5.00 \mathrm{~cd}$ & $6,00 \mathrm{c}$ \\
Rhizopus sp. & $6,00 \mathrm{~b}$ & $7,33 \mathrm{~b}$ & $8,33 \mathrm{~b}$ \\
Isolat Bakteri 1 & $2,33 \mathrm{c}$ & $6,33 \mathrm{bc}$ & $8,33 \mathrm{~b}$ \\
Isolat Bakteri 2 & $3,00 \mathrm{c}$ & $5,00 \mathrm{~cd}$ & $6,00 \mathrm{c}$ \\
\hline
\end{tabular}

Angka yang diikuti notasi huruf yang sama pada kolom yang sama menyatakan tidak berbeda nyata dengan ujijarak berganda Duncan taraf $5 \%$.

proses pemindahan kecambah dari tempat perkecambahan ke lapangan menjadi lebih cepat. Dengan demikian aplikasi jamur dan bakteri ini sangat potensial untuk menghemat waktu dan biaya pada tahapan pembibitan.

\section{Pengaruh Mikroba Endofitik Terhadap Tinggi Tanaman dan Perkembangan Akar Karet}

Berdasarkan analisis sidik ragam pemberian seed coating dengan spora endofitik dari biji karet segar berpengaruh nyata pada tinggi tanaman karet umur 1 minggu dan 2 minggu setelah tanam (MST). Biji yang telah mencapai stadia jarum ditanam di polibeg dan dirawat di rumah kaca. Hasil pengamatan menunjukkan bahwa pelapisan biji dengan spora Trichoderma koningii memiliki tinggi berbeda nyata dengan perlakuan lainnya pada pengamatan tinggi tanaman 1-2 MST. Tinggi tanaman yang paling tinggi pada perlakuan dengan menggunakan Trichoderma koningii diketemukan pada tanaman umur 1-3 MST. Sedangkan pada umur 4 MST terlihat bahwa tinggi tanaman tertinggi diketemukan pada perlakuan Aspergillus.

Sama halnya dengan pertumbuhan tinggi tanaman, perlakuan seed coating mikroba endofitik dari biji karet segar berpengaruh sangat nyata pada panjang akar tanaman karet dibandingkan kontrol. Respon tanaman terhadap masing-masing mikroba endofitik juga bervariasi. Hal ini dapat terlihat dari data pengamatan panjang akar tanaman menunjukkan bahwa perlakuan Trichoderma viridae berbeda nyata dengan perlakuan lainnya. Trichoderma sp. menghasilkan auksin inhibitor sehingga meningkatkan panjang akar. Mikroba yang menghasilkan IAA untuk meningkatkan efesiensi okupasi terhadap akar, dan okupasi akar tersebut menghindarkan akar tanaman dari ganguan mikroba patogen (Frank, 2011). Kedua kondisi tersebut menjadi faktor mengapa pertumbuhan tanaman karet menjadi lebih baik bila diinokulasi dengan mikroba endofitik. Nassar et al. (2005) menambahkan bahwa sejenis PGP juga ditemukan pada isolat jamur Williopsis saturnus, jamur endofitik di dalam akar jagung, mampu menghasilkan auksin secara in vitro di dalam media kultur jamur. Aktivitas jamur tersebut terbukti meningkatkan bobot kering akar, panjang akar, dan tunas bibit jagung. Jamur endofitik juga dilaporkan dapat menginduksi perakaran selama perkecambahan dan juga pertumbuhan akar dari stek Conifer (Doty, 2011). 
Tabel 2. Pertambahan panjang akar dan tinggi tanaman dari biji karet segar yang dilapisi dengan mikroba selama 30 HST

\begin{tabular}{llc}
\hline \multicolumn{1}{c}{ Perlakuan } & $\begin{array}{c}\text { Panjang akar } \\
(\mathrm{cm})\end{array}$ & $\begin{array}{c}\text { Pertambahan tinggi dari } \\
\text { pengukuran awal } \\
(\mathrm{cm})\end{array}$ \\
\hline Tanpa coating & $20,43 \mathrm{~b}$ & $9,10 \mathrm{f}$ \\
T. viridae & $36,63 \mathrm{a}$ & $10,98 \mathrm{c}$ \\
T. koningii & $28,87 \mathrm{ab}$ & $9,51 \mathrm{e}$ \\
Aspergillus sp. & $27,00 \mathrm{~b}$ & $11,88 \mathrm{a}$ \\
Rhizopus sp. & $21,43 \mathrm{~b}$ & $10,15 \mathrm{~d}$ \\
Isolat Bakteri 1 & $24,80 \mathrm{~b}$ & $11,90 \mathrm{a}$ \\
Isolat Bakteri 2 & $26,13 \mathrm{~b}$ & $11,41 \mathrm{~b}$ \\
\hline
\end{tabular}

- Angka yang diikuti notasi huruf yang sama pada kolom yang sama menyatakan tidak berbeda nyata pada Uji Jarak Berganda Duncan taraf 5\%.

- HST: hari setelah tanam

Selain itu mikroba endofitik ini mampu mengubah arsitektur akar menjadi lebih banyak rambut akar. Berdasarkan pengamatan visual terdapat variasi arsitektur akar antar perlakuan mikroba endofitik (Gambar 3). Secara umum, kemampuan akar dalam menyerap air dan mengakuisi unsur-unsur hara dari tanah ditentukan oleh rambut akar. Tanaman umumnya meningkatkan perkembangan akar baik dalam panjang maupun jumlah akar untuk mendapatkan nutrisi yang lebih banyak dari tanah yang terbatas kandungan nutrisinya (Giehl \& von Wirén, 2014). Perubahan arsitektur akar ini diduga dipengaruhi oleh okupasi perakaran oleh mikroba endofitik yang menghasilkan plant growth promotion (PGP) (Bjorkman, 2004; Doty, 2011) atau senyawa metabolit sekunder

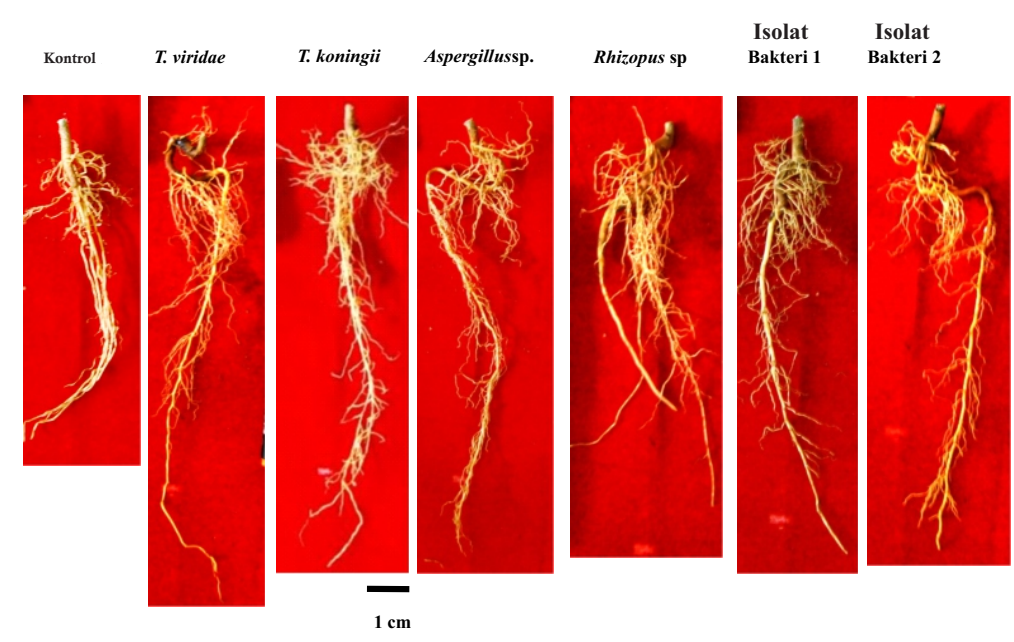

Gambar 3. Arsitektur akar tanaman dari biji karet segar umur 4 MST yang telah dilapisi dengan beberapa mikroba endofitik. 
lainnya (Schueffler \& Anke, 2011) yang menghambat serangan penyakit yang merusak akar. Perubahan arsitektur akar ini akan meningkatkan kemampuan akar dalam menyerap nutrisi sehingga pertumbuhan tanaman menjadi optimal. Kecepatan mikroba mengokupasi daerah perakaran dan sekresi beberapa jenis metabolit mempengaruhi kecepatan terbentuknya arsitektur akar.

Trichoderma sp. merupakan salah satu jenis jamur yang sering kali digunakan sebagai agen hayati pengendali jamur akar putih (Kaewchai \& Soytong, 2010). Trichoderma sp. dapat melisis dinding miselium dikarenakan kemampuannya menghasilkan enzim kitinase. Beberapa bakteri yang memiliki aktivitas enzim kitinase juga dapat menghambat pertumbuhan jamur akar putih (Kamil et al., 2007). Trichoderma sp. juga diketahui menghasilkan PGP yang memacu pertumbuhan tanaman (Bailey et al., 2011). Herlina \& Dewi (2010) melaporkan bahwa spesies Trichoderma sp. dapat juga berperan sebagai organisme pengurai.

Seperti halnya Trichoderma sp., Aspergillus sp. dapat mensintesis PGP dan juga menghasilkan asam salisilat yang meningkatkan toleransi terhadap cekaman. Tetapi Aspergillus sp. tidak memiliki metabolit yang mampu menghambat jamur akar putih dan hanya menghambat jika ada kontak dengan jamur akar putih (Kaewchai \& Soytong, 2010). Maningsih \& Anas (1996) melaporkan bahwa Aspergillus sp. dapat meningkatkan kelarutan $\mathrm{P}$ dari $\mathrm{AlPO}_{4}$ sebesar $135 \%$ dan dapat meningkatkan $\mathrm{P}$ larut pada tanah Ultisol sebesar 30,4\% dibandingkan kontrol. Aplikasi jamur endofitik meningkatkan toleransi tanaman terhadap cekaman kekeringan (Bailey et al., 2011) dan cekaman garam (Waqas et al., 2012).

\section{Kesimpulan}

Beberapa isolat jamur dan bakteri berhasil dieksplorasi dari biji karet segar, sedangkan pada biji karet kurang segar hanya diperoleh satu isolat jamur. Trichoderma sp., Aspergillus sp., Rhizopus sp. dan dua isolat bakteri endofitik dari biji karet segar berperan dalam mempercepat perkecambahan biji karet dan pertumbuhan awal tanaman. Jamur dan bakteri endofitik dari biji karet segar ini juga mempengaruhi arsitektur perakaran tanaman karet berupa peningkatan panjang akar dan jumlah rambut akar.

\section{Daftar Pustaka}

Akbari, G., Sanavy, S., \& Yousefzadeh, S. (2007). Effect of auxin and salt stress $(\mathrm{NaCl})$ on seed germination of wheat cultivars (Triticum aestivum L.). Pakistan Journal of Biological Sciences, 10(15), 25572561. doi:10.3923/pjbs.2007.2557.2561

Angel, S. M. M., Badillo, M. G. C., \& Osuna, M. A. I. (2011). The plant growthpromoting fungus Aspergillus ustus promotes growth and induces resistance against different lifestyle pathogens in Arabidopsis thaliana. Journal of Microbiology and Biotechnology, 21(7), 686696.

Bailey, B. A., Bae, H., Melnick, R., \& Crozier, J. (2011). The endophytic Trichoderma hamatum isolate DIS $219 \mathrm{~b}$ enhances seedling growth and delays the onset of drought stress in Theobroma cacao. In A. M. Pirttila \& A. C. F. Frank (Eds.), Endophytes of Forest Trees (pp. 157-172). New York, USA: Springer.

Björkman, T. (2004). Effect of Trichoderma colonization on auxin-mediated regulation of root elongation. Plant Growth Regulation, 43(1), 89-92.

Djaafar, T., Rahayu, E., \& Rahayu, S. (2001). Kontaminasi kapang selama penyimpanan benih jagung dan hubungannya dengan daya kecambah. Jurnal Ilmu Pertanian Indonesia, 10(2), 46-49.

Doty, S. L. (2011). Growth-promoting endophytic fungi of forest trees. In A. M. Pirttila \& A. C. F. Frank (Eds.), Endophytes of Forest Trees (pp. 151-156). New York, USA: Springer. 
Frank, A. C. (2011). The genomes of endophytic bacteria. In A. M. Pirttila \& A. C. F. Frank (Eds.), Endophytes of forest trees (pp. 107-136). New York, USA: Springer.

Ge, H. M., Shen, Y., Zhu, C. H., Tan, S. H., Ding, H., Song, Y. C., \& Tan, R. X. (2008). Penicidones A-C, three cytotoxic alkaloidal metabolites of an endophytic Penicillium sp. Phytochemistry, 69(2), 571576.

Giehl, R. F., \& von Wirén, N. (2014). Root nutrient foraging. Plant Physiology, 166(2), 509-517.

Griffin, M. R. (2014). Biocontrol and bioremediation: two areas of endophytic research which hold great promise. In V. C. Verma \& A. C. G. Gange (Eds.), Advances in Endophytic Research (pp. 257-282). New Delhi, India: Springer.

Hanudin, E. S., Mihardja, S., \& Sanusie, I. (2002). Mikroba antagonis sebagai agen hayati pengendali penyakit tanaman: Balai Penelitian Tanaman Hias.

Hasan, H. (2002). Gibberellin and auxin production by plant root-fungi and their biosynthesis under salinity-calcium interaction. Rostlinna vyroba, 48(3), 101-106.

Herlina, L., \& Dewi, P. (2010). Penggunaan kompos aktif aktif trichoderma harzianum dalam meningkatkan pertumbuhan. Sainteknol: Jurnal Sains dan Teknologi, $8(2), 11-25$.

Ilyas, S. (2001). Mutu Benih. Diakses dari Pontianak.

Kaewchai, S., \& Soytong, K. (2010). Application of biofungicides against Rigidoporus microporus causing white root disease of rubber trees. Journal of Agricultural Technology, 6(2), 349-363.

Kamil, Z., Saleh, M., \& Moustafa, S. (2007). Isolation and identification of rhizosphere soil chitinolytic bacteria and their potential in antifungal biocontrol. Global Journal of Molecular Sciences, 2(2),57-66
Malfanova, N. V. (2013). Endophytic bacteria with plant growth promoting and biocontrol abilities. (Doctoral Thesis), Leiden University.

Maningsih, G., \& Anas, I. (1996). Peranan Aspergillus niger dan bahan organik dalam transformasi $\mathrm{P}$ anorganik tanah. Pemberitaan Penelitian Tanah dan Pupuk. 14(1), 31-36.

Mari, M., \& Guizzardi, M. (1998). The postharvest phase: emerging technologies for the control of fungal diseases. Phytoparasitica, 26(1), 59-66.

Maria, P. D. (2002). Eksplorasi dan uji antagonisme bakteri rhizosfer tanah dan endofit akar untuk pengendalian penyakit layu ( $F$. oxysporum $f$. sp. cubense) pada pisang (Musa paradisiaca). (Skripsi), Institut Pertanian Bogor, Bogor.

Nandhini, S., Sendhilvel, V., \& Babu, S. (2012). Endophytic bacteria from tomato and their efficacy against Fusarium oxysporum $\mathrm{f}$. sp. lycopersici, the wilt pathogen. Journal of Biopesticides, 5(2), 178-185.

Nassar, A. H., E1-Tarabily, K. A., \& Sivasithamparam, K. (2005). Promotion of plant growth by an auxin-producing isolate of the yeast Williopsis saturnus endophytic in maize (Zea mays L.) roots. Biology and Fertility of Soils, 42(2), 97-108.

Novariza, D. A., Lubis, L., Sitepu, S. F., \& Tistama, R. (2015). Exploration and characterization of microorganisms from rubber seed and the benefits for rubber plant growth (Hevea brassiliensis Muell. Arg.). Agroekoteknologi, 4(1), 1925-1936.

Osono, T. (2014). Diversity and ecology of endophytic and epiphytic fungi of tree leaves in Japan: a review. In V. C. Verma \& A. C. G. Gange (Eds.), Advances in Endophytic Research (pp. 3-26). New Delhi, India: Springer. 
Pohjanen, J., Koskimäki, J. J., \& Pirttilä, A. M. (2014). Interactions of meristem-associated endophytic bacteria. In V. C. Verma \& A. C. G. Gange (Eds.), Advances in Endophytic Research (pp. 103-113). New Delhi, India: Springer.

Ratnasari, J., \& Isnawati, R. E. (2014). Uji antagonis cendawan agens hayati terhadap cendawan Cercospora musae penyebab penyakit sigatoka secara in vitro. Lenterabio, 3(2), 129-135.

Resende, M., Paixão, i., Jakoby, I. C. M. C., dos Santos, L. C. R., Soares, M. A., Pereira, F., . . . Silva, F. G. (2014). Phosphate solubilization and phytohormone production by endophytic and rhizosphere Trichoderma isolates of guanandi (Calophyllum brasiliense Cambess). African Journal of Microbiology Research, 8(27), 26162623.

Schueffler, A., \& Anke, T. (2011). Antimicrobial compounds from tree endophytes. In A. M. Pirttilia \& A. C. Frank (Eds.), Endophytes of Forest Trees (pp. 265294). Heidelberg, Germany: Springer.

Siagian, N. (2008). Pembibitan dan pengadaan bahan tanaman karet unggul. Medan: Balai Penelitian Sungei Putih.

Sukarman, \& Seswita, D. (2015). Pengaruh lokasi penyimpanan dan pelapisan (coating) benih dengan pestisida nabati terhadap mutu benih rimpang jahe. Buletin Penelitian Tanaman Rempah dan Obat, 23(1), 1-10.

Sulistiono, S., Soemardi, I., \& Purwantoro, A. (2004). Kandungan auksin asam (3-indol asetat) pada tahap perkembangan buah kacang tanah (Arachis hypogea (L.) Merr). Journal of Biological Researches, 9(2), 79-85.
Suryanto, D., \& Munir, E. (2006). Potensi isolat bakteri kitinolitik lokal untuk pengendalian jamur hayati. Tulisan disajikan pada Prosiding Seminar Hasil-hasil Penelitian Lembaga Penelitian Universitas Sumatera Utara, Medan.

Taiz, L., \& Zeiger, E. (2002). Plant Physiology 3th Edition. Massachusetts: Sinauer Associated Inc. Publisher.

Tenguria, R. K., Khan, F. N., \& Quereshi, S. (2011). Endophytes-mines of pharmacological therapeutics. World Journal of Science and Technology, 1(5), 127149.

Ting, A. S. Y. (2014). Biosourcing endophytes as biocontrol agents of wilt diseases. In V. C. Verma \& A. C. G. Gange (Eds.), Advances in Endophytic Research (pp. 283-300). New Delhi, India: Springer.

Tistama, R., Widyastuti, U., \& Suharsono, S. (2013). Isolasi dan karakterisasi gen sitrat sintase bakteri Pseudomonas aeruginosa dari filosfer Hevea brasiliensis muell. arg. Jurnal Penelitian Karet, 31(2), 127-138.

Unterseher, M. (2011). Diversity of fungal endophytes in temperate forest trees. In A. M. Pirttilia \& A. C. Frank (Eds.), Endophytes of forest trees (pp. 31-46). Heidelberg, Germany: Springer.

Vlot, A. C., Dempsey, D. M. A., \& Klessig, D. F. (2009). Salicylic acid, a multifaceted hormone to combat disease. Annual Review of Phytopathology, 47, 177-206.

Waqas, M., Khan, A. L., Kamran, M., Hamayun, M., Kang, S.-M., Kim, Y.-H., \& Lee, I.-J. (2012). Endophytic fungi produce gibberellins and indoleacetic acid and promotes host-plant growth during stress. Molecules, 17(9), 10754-10773. 
Welty, R., Azevedo, M., \& Cooper, T. (1987). Influence of moisture content, temperature, and length of storage on seed germination and survival of endophytic fungi in seeds of tall fescue and perennial ryegrass. Phytopathology, 77(6), 893-900. 